\title{
パラジウムメンブレンリアクターを用いた $\mathrm{Pt} / \mathrm{ZnO}$ 触媒上でのブタンとプロパンの脱水素反応
}

\author{
五十嵐 哲*, 太田道貴 ${ }^{+1}$ \\ 工学院大学工学部化学工学科, 192 東京都八王子市中野町 2665-1
}

(平成 5 年 6 月 3 日受理)

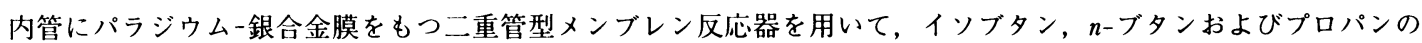
低温脱水素のための触媒についての研究を行った。反応側で生成した水素は分離膜を透過し, 分離側で空気中の酸素 と反応する。試験した触媒のなかで, $\mathrm{Pt}(0.5 \mathrm{wt} \%) / \mathrm{ZnO}$ 触媒がイソブタンのイソブチレンへの脱水素のために最も

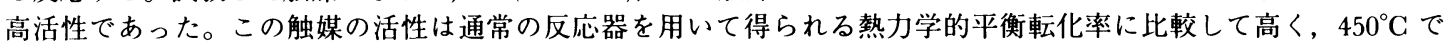
$45 \%$ 以上のイソブタン転化率と扰よそ $99 \%$ のイソブチレンへの選択率を示した。さらに, $\mathrm{Pt}(0.5 \mathrm{wt} \%) / \mathrm{ZnO}$ 触媒 はプロパンと $n$-ブタンの脱水素にも有効であった。しかしながら, Pt 原料の塩化白金酸中に含まれる塩素によると 考えられる $\mathrm{Pt} / \mathrm{ZnO}$ 触媒の被毒と，酸化によると考えられるパラジウム一銀合金膜の劣化が観測された。
\end{abstract}

\section{1. 緒言}

$\mathrm{C}_{3}, \mathrm{C}_{4}$ オレフィンは, ガソリン基剤の MTBE やアルキレー ト, MMA および各種ポリマーの原料としてL業的に重要で あるが, 現在は FCC オフガスやエチレンクラッカーの副生成 物として得られていることから, その生産には限度がある。そ して, 今後の $\mathrm{C}_{3}, \mathrm{C}_{4}$ オレフィンの需要の増加, 特に MTBE のための大量のイソブチレンの需要を考えると, 早急に他の製 造法を開拓することが望まれる。そこで， $\mathrm{C}_{3}, \mathrm{C}_{4}$ オレフィン の新たな供給ルートとして, 燃料としての評価にとどまってい る $\mathrm{LPG}$ 中の $\mathrm{C}_{3}, \mathrm{C}_{4}$ 留分やスペントプロパン, ブタンを原料 とする脱水素プロセスが魅力のある方法であると考えられ る'。

現在, 脱水素反応は平衡論的な制䄪から $600^{\circ} \mathrm{C}$ 程度の高温 で】業的な反応操作が行われている。このために，製品収率が 低く, 触媒に要求される条件も厳しく, また希釈剤かつ熱媒体 としての大量のスチームを使用することから, エネルギーコス トもきわめて高いものとなっている。さらに, 高温反応に由来 する触媒休へ析出したカーボンの除去, 触媒再生部を必要とし て抢り，技術的にも問題点が多い。このように，現行のプロセ スは大きな課題を残しており, 革新的なプロセスの構築が望ま れている2。

さて, 最近, 水素透過性にすぐれた種々の分離膜が開発され つつあり、これらの分離膜を用いた友志分離法が提案されてい る。文忍分離法は技術的には開発途上にあり，改良すべき点が

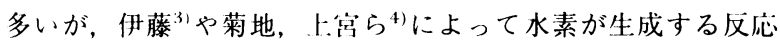
に术心分離法を適用した報告がなされつつあり，特に分離膜を 透過した水素を酸素含有のスウィープガスによって酸化除去す る方法,つまりみかけトの酸化脱水素反応を行う方法が注目さ

* 連絡先

+1)(現在) 新日鐵化学:(株)技術研究所, 804 北九州市戸畑区 中原先の浜 46-51
れる5)。この方法では, 透過側の水素分圧が常にゼロとなるの で, 水素透過の推進力が大きくなり転化率が向上するととも に，水素の燃焼熱を脱水素反応部へ供与できるという利点を有 している。反応分離法の脱水素反応への適用は, 大幅な省工ネ ルギー化とプロセスの簡略化を可能とするが, 反応温度の低温 化に伴い, 使用する触媒に要求される条件は現在のそれとは全 く異なることが予想される。すなわち，従来は反応温度が高温 であるがために，主に金属酸化物が触媒として使用されている が, 低温での反応が可能となると水素化反応に汎用されている $\mathrm{Pt}, \mathrm{Cu}, \mathrm{Ni}$ などの金属触媒が有効となる可能性が高い6)。

以上に述へてきた背景をもとにして，本研究は反応分離法に より $\mathrm{C}_{3}, \mathrm{C}_{4}$ 類の脱水素反応を行うことを目的としている。具 体的には, 内管に水素透過能をもつ膜管を配置した二重管型入 ンブレンリアクターを用いることによって，反応系から生成水 素を選択的に除外し，さらに透過水素を酸化除去することによ って，平衡論的制約を回避することを企画した。そして，平衡 論的制約がなくなったときには低温での反応が可能となること から, 従来の高温型金属酸化物触媒に代わる新規な低温高活性 触媒の開発を行うとともに, 反応操作因子に検討を加えること によって, 新しい脱水素プロセスの構築を図ろうとするもので ある*1。

\section{2. 実験}

\section{1. 触媒}

$\mathrm{Pt}, \mathrm{Cu}, \mathrm{Ni}$ などの金属と種々の担体からなる触媒を含浸法 により調製した。金属源として，貴金属のためには塩化物を， $\mathrm{Cu}$ と $\mathrm{Ni}$ のためには硝酸塩を用いた。担体原料としては, $\mathrm{ZnO}$ : 和光純薬工業製, 塩基性炭酸亜鉛, $\mathrm{Al}_{2} \mathrm{O}_{3}$ : 触媒学会参 照触媒, “JRC-ALO-4”, $\mathrm{ZrO}_{2}$ : 北興化学 1 業製, 部分安定化

*1 最近, 菊地, 松田らによって, イソブタンの脱水素のため の $\mathrm{Pt}-\mathrm{Sn} / \mathrm{Al}_{2} \mathrm{O}_{3}$ 触媒についての報告 (Appl. Catal., 96, 3 (1993)）がなされた。 
ジルコニア $\left(\mathrm{Y}_{2} \mathrm{O}_{3} 2.5 \mathrm{~mol} \%\right.$ 含有), $\mathrm{Cr}_{2} \mathrm{O}_{3}$ : 半井化学薬品製, $\mathrm{Cr}_{2} \mathrm{O}_{3} \cdot x \mathrm{H}_{2} \mathrm{O}, \mathrm{TiO}_{2}$ : 触媒学会参照触媒, “JRC-TIO-1", $\mathrm{MgO}$ : 関東化学製, 塩基性炭酸マグネシウム, $\mathrm{SiO}_{2}$ : 富士デ ヴィソン化学製，“ID ゲル”を用い，それぞれについて $500^{\circ} \mathrm{C}$ での焼成処理を施した。また，硝酸ガリウムを用いて含浸法に よって $\mathrm{Ga}_{2} \mathrm{O}_{3}(10 \mathrm{wt} \%)-\mathrm{Al}_{2} \mathrm{O}_{3}$ 担体も調製した。得られた含浸 乾燥後の触媒については, 反応器に立てんする前に $\mathrm{Cu}$ 触媒は $300^{\circ} \mathrm{C}$ ，その他の触媒は $500^{\circ} \mathrm{C}$ での空気気流中での焼成処理と 水素気流中での還元処理を行った。金属担持量は，貴金属では $0.5 \mathrm{wt} \%$ を標準とし，Cuと Niでは $10 \mathrm{wt} \%$ とした。なお比 較のために, 脱水素触媒として知られている $\mathrm{Cr}_{2} \mathrm{O}_{3} / \mathrm{Al}_{2} \mathrm{O}_{3}$ 触 媒》をも用意した。

\section{2. 性能試験}

反応器としてメンブレンリアクターを用いた。メンブレンリ アクターは二重管であり，内管の内側を反応側，外側を透過側 とした。内管は長さが $374 \mathrm{~mm}$ であり，中央部に水素分離の ためのパラジウム合金管 $(\mathrm{Pd}-\mathrm{Ag}(23 \mathrm{wt} \%)$ : 田中貴金属 I. 業 製, 内径 $10 \mathrm{~mm}$, 厚さ $0.15 \mathrm{~mm}$, 長さ $50 \mathrm{~mm}$ ) をもつステン レスーパラジウム合金ーステンレス管である。両側のステンレス 管（SUS304，外径 $10 \mathrm{~mm}$, 内径 $7 \mathrm{~mm}$, 長さ $162 \mathrm{~mm}$ )をパラ ジウム合金管に銀ロウ溶接した。触媒床は熱電対保護管に固定 された目血で支持し，その長さは内管のパラジウム合金管の中 央部の $50 \mathrm{~mm}$ である。外管にはステンレス管（SUS304，外径 3/4”，内径 $16.6 \mathrm{~mm}$ ）を用い，外部にヒーターを卷いて直熱 型とした。反応器全体は，スウェジロック製のキャップ 2 種 $(3 / 4 ”, 10 \mathrm{~mm})$ と，ユニオンおよびユニオンティーをアルゴ ン溶接したもので組み立ててられ，シールにはテフロン製のフェ ルールを用いた。反応器が高温のときのシール部からの漏れを 防ぐために，シール部にビニール管を巻き冷却水を流した。な お, 反応器中央部の熱電対保護管の中と外管とヒーターの間 に，それぞれ測定用と制御用の熱電対を設置した。

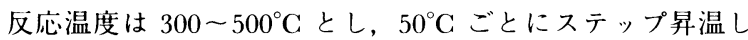
た。触媒量は $3.8 \mathrm{ml}$ であり, 内管の内側にイソブタン, プロ パン，あるいは $n$-ブタン(いずれも純度 $99.5 \%)$ を $5 \mathrm{ml} / \mathrm{min}$, 内管の外側に空気を $100 \mathrm{ml} / \mathrm{min}$ の流速で流した。透過水素は 膜の外側表面で空気中の酸素によって酸化除去される。なお， パイレックスガラス製の通常の非分離型反応器を用いた実験も 行った。

\section{3. 結果と考察}

\section{1. 各触媒の性能}

プロパンを原料として通常の非分離型反応管（触媒量 0.9 $\mathrm{m} l$ ) を用いた予備実験の結果から，次のことが明らかとなっ た。すなわち， $\mathrm{Pt} / \mathrm{ZnO}$ 触媒を用いたときに, $400^{\circ} \mathrm{C}$ で平衡転 化率 $(4.1 \%)$ に近い転化率 $(3.6 \%)$ が得られ, 高いプロピレ ン選択率 $(99.7 \%)$ を示した。 $\mathrm{Pt} / \mathrm{Al}_{2} \mathrm{O}_{3}$ 触媒では転化率は高 い $(3.9 \%)$ ものの, プロピレン選択率は低下 $(77.2 \%)$ した。 $\mathrm{Cu}$ 系触媒については担体の種類を変えても， $400^{\circ} \mathrm{C}$ で転化率 が $1 \%$ を大きく越えるものは見い出せなかった。また，Ni 系 触媒では担体として $\mathrm{SiO}_{2}, \mathrm{Nb}_{2} \mathrm{O}_{5}$ ，および $\mathrm{ZrO}_{2}$ を用いたとき に $400^{\circ} \mathrm{C}$ で転化率が $20 \sim 40 \%$ であったが，生成物のほとんど はメタンであり物質収支もよくなかった。さらに Cu 系触媒に
Table 1 Catalytic Activities and Selectivities of Various Supported Pt Catalysts for Dehydrogenation of Isobutane at $450^{\circ} \mathrm{C}$

\begin{tabular}{lcc}
\hline \multicolumn{1}{c}{ Catalyst } & $\begin{array}{c}\text { Conversion of } \\
\text { isobutane }[\%]\end{array}$ & $\begin{array}{c}\text { Selectivity for } \\
\text { isobutylene }[\%]\end{array}$ \\
\hline Equilibrium & 18.0 & - \\
\hline $\mathrm{Pt} / \mathrm{ZnO}$ & 46.8 & 98.9 \\
$\mathrm{Pt} / \mathrm{Ga}_{2} \mathrm{O}_{3} \cdot \mathrm{Al}_{2} \mathrm{O}_{3}{ }^{\text {a) }}$ & 22.8 & 49.2 \\
$\mathrm{Pt} / \mathrm{ZrO}_{2}{ }^{\text {a) }}$ & 20.8 & 83.8 \\
$\mathrm{Pt} / \mathrm{Al}_{2} \mathrm{O}_{3}$ & 5.9 & 49.8 \\
$\mathrm{Pt} / \mathrm{Cr}_{2} \mathrm{O}_{3}$ & 4.1 & 98.5 \\
$\mathrm{Pt} / \mathrm{TiO}_{2}$ & 2.9 & 89.2 \\
$\mathrm{Pt} / \mathrm{MgO}$ & 0.3 & 99.1 \\
$\mathrm{Pt} / \mathrm{SiO}_{2}$ & 0.1 & 90.1 \\
$\mathrm{Cr}_{2} \mathrm{O}_{3} / \mathrm{Al}_{2} \mathrm{O}_{3}{ }^{\text {a) }}$ & 9.4 & 86.0 \\
\hline
\end{tabular}

a) Carbon deposition

Table 2 Catalytic Activities and Selectivities of Various Metal Catalysts Supported on $\mathrm{ZnO}$ for Dehydrogenation of Isobutane at $450^{\circ} \mathrm{C}$

\begin{tabular}{ccc}
\hline Catalyst & $\begin{array}{c}\text { Conversion of } \\
\text { isobutane }[\%]\end{array}$ & $\begin{array}{c}\text { Selectivity for } \\
\text { isobutylene }[\%]\end{array}$ \\
\hline $\mathrm{Pt} / \mathrm{ZnO}$ & 46.8 & 98.9 \\
$\mathrm{Ir} / \mathrm{ZnO}$ & 2.7 & 89.1 \\
$\mathrm{Pd} / \mathrm{ZnO}$ & 0.1 & 87.0 \\
$\mathrm{Ni} / \mathrm{ZnO}$ & 0.8 & 95.0 \\
\hline
\end{tabular}

ついて, $\mathrm{MgO}$ をベースとして担体を複令化した触媒や, 添加 $\mathrm{Ni}$ 量を変化させた二元系触媒の性能を検討したが，活性の问 上は認められなかった。

さて, Table 1 は, イソブタンを住螈料として，パラジ ウム合金管の外側に向流で空気をスウィープしたときの $450^{\circ} \mathrm{C}$ における Pt 系触媒の性能である。比較のために示した, 従 来，スチーム雲用気下で高温で用いられている $\mathrm{Cr}_{2} \mathrm{O}_{3} / \mathrm{Al}_{2} \mathrm{O}_{3}$ 触媒には多少の活性があるものの, イソブチレン選択率は低 い。それに対して, $\mathrm{Pt}$ 系触媒では $\mathrm{ZnO}, \mathrm{Ga}_{2} \mathrm{O}_{3}-\mathrm{Al}_{2} \mathrm{O}_{3}$ 、拈よ び $\mathrm{ZrO}_{2}$ などを担体としたときに比較的活性があり，特に $\mathrm{ZnO}$ 担体では平衡転化率の 2.6 倍のイソブタン転化率と $100 \%$ 近いイソブチレン選択率を示している。イソブチレン以 外の生成物は, ごく微量の $\mathrm{C}_{3}, 1$-ブテン, cis-2-ブテン, およ び trans-2-ブテンであった。次に，Table 2 に $\mathrm{nO}$ を担体と する各種の金属触媒の $450^{\circ} \mathrm{C}$ での性能を示したが, $\mathrm{Pt} / \mathrm{ZnO}$ 触媒が他の触媒と比較してはるかに高い性能を示している。

Fig. 1 は, 最も性能がすぐれていた $\mathrm{Pt} / \mathrm{ZnO}$ 触媒の性能の 温度依存性である。すべての反応温度で平衡転化率を大きく越 える活性とすぐれたイソブチレン選択率を示し，イソブタンか らイソブチレンへの脱水素反忍がきわめて選択的に進行してい ることがわかる。Fig. 2 は，プロパンを反応原料としたとき の $\mathrm{Pt} / \mathrm{ZnO}$ 触媒の性能であるが，イソブタンを反応原料とし たときと同様に，すべての反応温度において平衡転化率を越え る高い転化率が得られた。プロピレン選択率は $99 \%$ 以上であ り,ごく微量のメタンとエタンが副生した。Fig. 3 は, $n$-ブ タンを反応原料としたときの結果である。この場命も，すべて の反応温度において平衡転化率を越える高い転化率と $100 \%$ 


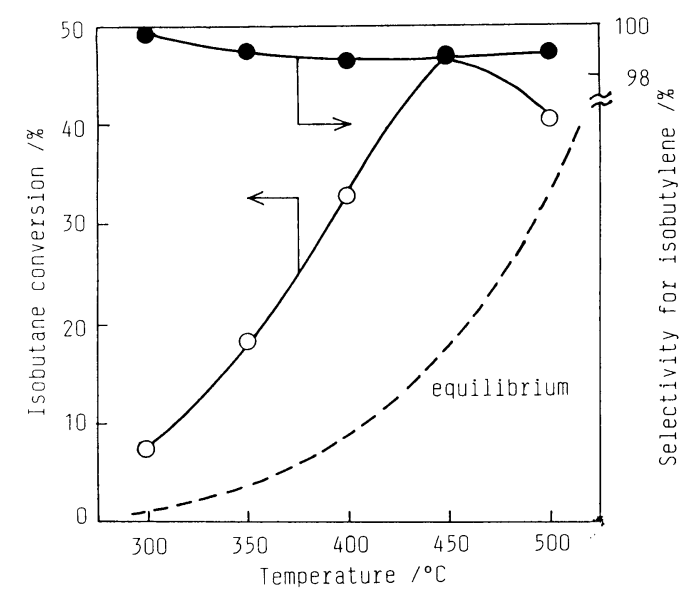

Fig. I Catalytic Performance of $\mathrm{Pt}(0.5 \mathrm{wt} \%) / \mathrm{ZnO}$ Catalyst for Dehydrogenation of Isobutane

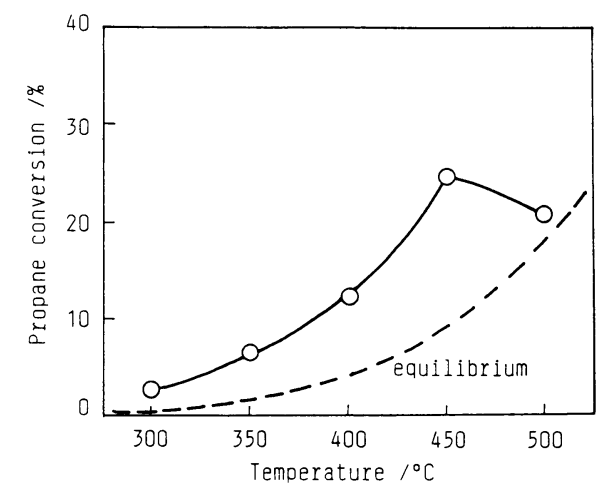

Fig. 2 Cionversion of Propane over $\mathrm{Pt}(0.5 \mathrm{wt} \%) / \mathrm{ZnO}$ Catalyst

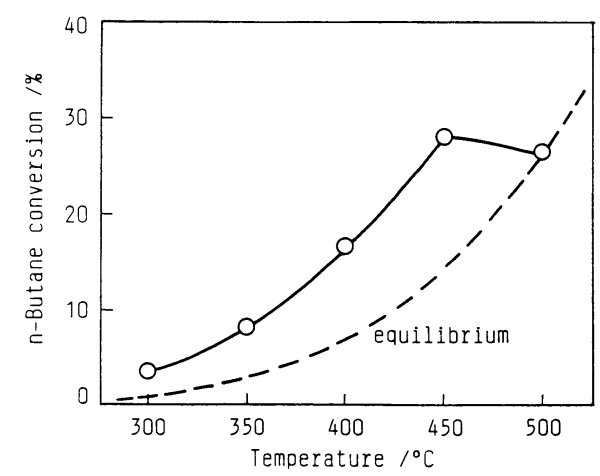

Fig. 3 Cionversion of $n$-Butane over $\mathrm{Pt}(0.5 \mathrm{wt} \%) / \mathrm{ZnO}$ Catalyst

近い直鎖状ブテン選択率が得られた。さらに Fig. 4 は，実験 で得られた直鎖状ブテンの組成と，熱力学的な平衡組成の計算 值を転化率に対してプロットしたものである。図より，1ーブテ ン, trans-2-ブテン, cis-2-ブテンの割合についての実験值と計 算值がほぼ一致していることが明らかである。なお，生成物の 一つである 1ーブテンはポリー1ーブテンや LLDPE の原料とな ク，㨁鎖状ブテンのなかで工業的に最も重要であるが, $n$-ブ夕

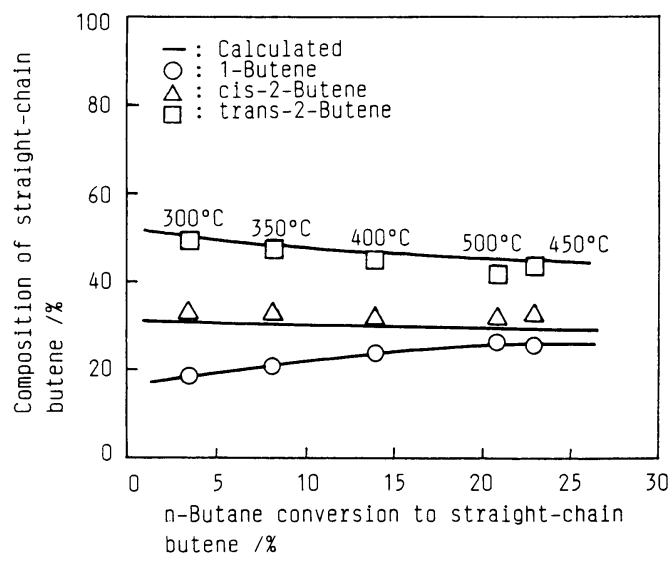

Fig. 4 Comparison of Experimental and Calculated Compositions of Straight-chain Butene for $n$-Butane Dehydrogenation over $\mathrm{Pt}(0.5 \mathrm{wt} \%) / \mathrm{ZnO}$ Catalyst

ンから 1ーブテンを得るには熱力学的に高温, すなわち高い転 化率を必要とする。したがって, 従来の脱水素プロセスで1ブテンを大量に得ようとすれば, 高い反応温度によって並発す る分解反応のために，さほど1-ブテンの収率が増加しないこ とが予想される。しかしながら, 本実験で示したように, メン ブレンリアクターを用いることによって，低温でも高い転化率 が得られれば比較的容易に1ーブテンを製造することが可能に なると考えられる。このように, $\mathrm{Pt} / \mathrm{ZnO}$ 触媒を用いた反応分 離法によって，比較的低温で高成績が得られたことは現行プロ 七スの多くの問題点を解決できる可能性を呈示したといえよ う。

なお, Figs. 1 3 にみられるように, いずれの反応原料を 用いても $500^{\circ} \mathrm{C}$ では転化率は減少しているが, 非分離型の反 応管を用いて平衡転化率よりも低い転化率となるような触媒量 $(0.5 \mathrm{ml})$ で反応を行ったときには， $500^{\circ} \mathrm{C}$ でも転化率は単調 に増加していることから, $500^{\circ} \mathrm{C}$ での活性低下は $\mathrm{Pt} / \mathrm{ZnO}$ 触 媒の劣化のためではないことが予想できる。

\section{2. $\mathrm{Pt} / \mathrm{ZnO}$ 触媒の $\mathrm{Pt}$ 担持量の影幚}

Table 3 は, $\mathrm{Pt} / \mathrm{ZnO}$ 触媒の $450^{\circ} \mathrm{C}$ でのイソブタンの脱水 素反応の性能に対する $\mathrm{Pt}$ 担持量の影響を示したものである。 表から明らかなように, Pt 担持量が増加すると活性は担持量 が $0.5 \mathrm{wt} \%$ で最大值を示し，その後は大きく減少している。

一般に，担持貴金属触媒を用いたときには，担持量が $1 〜 3$ $\mathrm{wt} \%$ で活性の最大值をもつことが多いが, 得られた結果は異 なったものとなっている。Fig. 5 は, Table 3 に示した各触

Table 3 Effect of Pt Content on Catalytic Activity and Selectivity of $\mathrm{Pt} / \mathrm{ZnO}$ Catalyst for Dehydrogenation of Isobutane at $450^{\circ} \mathrm{C}$

\begin{tabular}{ccc}
\hline $\begin{array}{c}\text { Pt content } \\
{[\text { wt \% ] }}\end{array}$ & $\begin{array}{c}\text { Conversion of } \\
\text { isobutane [\%] }\end{array}$ & $\begin{array}{c}\text { Selectivity for } \\
\text { isobutylene [\%] }\end{array}$ \\
\hline 0.25 & 36.2 & 99.4 \\
0.5 & 46.8 & 98.9 \\
1.0 & 7.9 & 99.4 \\
3.0 & 5.6 & 91.6 \\
\hline
\end{tabular}




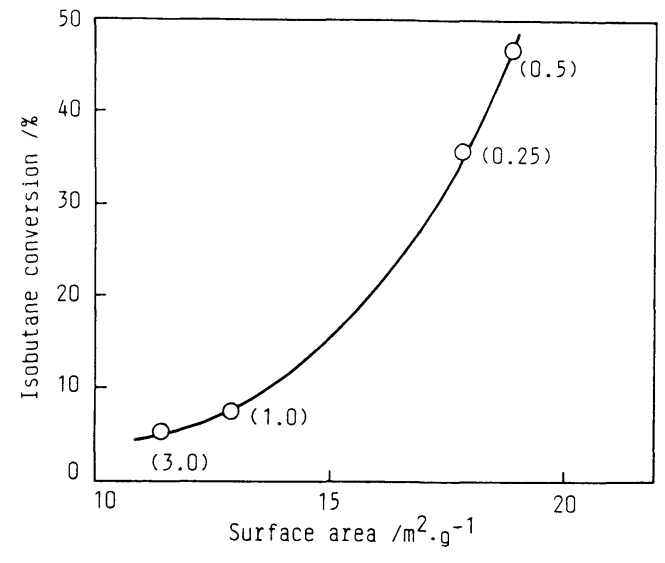

Contents of $\mathrm{Pt}(\mathrm{wt} \%)$ are shown in parentheses.

Fig. 5 Relationship between Conversion of Isobutane at $450^{\circ} \mathrm{C}$ and BET Specific Surface Area of $\mathrm{Pt} / \mathrm{ZnO}$ Catalyst Used

媒上でのイソブタン転化率と反応後の触媒の BET 比表面積の 関係を示したものであるが，触媒活性は BET 比表面積に対応 していることがわかる。本反応系においては触媒活性は Pt 表 面積に依存すると考えられるが, 高担持量での活性低下の原因 として Pt の出発原料である塩化白金酸に含まれる塩素が $\mathrm{Pt}$ 表面積に影響を与えるであろう BET 比表面積の低下をもたら したと考えることができる。すなわち，塩化白金酸を水に溶か すと，次のような配位子交換反応と解離反応が生じ ${ }^{8)}$,

$\mathrm{H}_{2} \mathrm{PtCl}_{6} \cdot 6 \mathrm{H}_{2} \mathrm{O} \rightarrow \mathrm{PtCl}_{6}{ }^{2-}+2 \mathrm{H}^{+}+6 \mathrm{H}_{2} \mathrm{O}$

$\mathrm{PtCl}_{6}{ }^{2-}+\mathrm{H}_{2} \mathrm{O} \rightleftarrows\left[\mathrm{PtCl}_{5} \mathrm{H}_{2} \mathrm{O}\right]^{-}+\mathrm{Cl}$

$\left[\mathrm{PtCl}_{5} \mathrm{H}_{2} \mathrm{O}\right]^{-} \rightleftarrows\left[\mathrm{PtCl}_{5} \mathrm{OH}\right]^{2-}+\mathrm{H}^{+}$

生成した塩酸が担体の $\mathrm{ZnO}$ と反応して, $\mathrm{ZnCl}_{2}$ を生成するこ とが予想される。

$\mathrm{ZnO}+2 \mathrm{HCl} \rightarrow \mathrm{ZnCl}_{2}+\mathrm{H}_{2} \mathrm{O}$

実際に, $\mathrm{Pt}(3.0 \mathrm{wt} \%) / \mathrm{ZnO}$ 触媒の焼成後と還元後に，それぞ れパイレックスガラス製の炉管内側に $\mathrm{ZnCl}_{2}$ と思われる潮解 性の白色物質の付着か観察されたことは，この予想を裏付ける ものである。 $\mathrm{ZnCl}_{2}$ は融点が $283^{\circ} \mathrm{C}$ ，沸点が $732^{\circ} \mathrm{C}$ であるた めに，焼成や還元処理時に揮発しにくく，高担持量触媒上では $\mathrm{ZnCl}_{2}$ が溶解して BET 比表面積の減少やPt表面積の減少を招 いたと考えることができる。

\section{3. 空間速度の影簀}

$\mathrm{Pt}(0.5 \mathrm{wt} \%) / \mathrm{ZnO}$ 触媒の性能に及ぼす空間速度 $(S . V$.$) の$ 影響を調べるために，イソブタンの供給速度を変化させた実験 を行った。Fig. 6 は, イソブタン転化率と空間速度の関係で ある。 $S . V .=150 \mathrm{~h}^{-1}, 300 \mathrm{~h}^{-1}$ のときにはイソブチレン選択率 は $99 \%$ 以上であった。 $S . V .=150 \mathrm{~h}^{-1}$ では， $S . V .=73.6 \mathrm{~h}^{-1}$ (Fig. 1) の結果と同様に, $500^{\circ} \mathrm{C} に$ 扔いて転化率の低下がみ られ平衡転化率を下回った。さらに，S.V.=300 $\mathrm{h}^{-1}$ では, 反 応温度 $450^{\circ} \mathrm{C}$ 以上で平衡転化率を越えなかった。いずれにし ても, 空間速度が大きくなると転化率が減少し, 特に反心温度 が高くなるとその傾问が顕著になることがわかる。

\section{4. 触媒性能の経時変化とその原因}

$450^{\circ} \mathrm{C}, S . V .=73.6 \mathrm{~h}^{-1}$ （イソブタン流量: $5 \mathrm{ml} / \mathrm{min}$ )の条 件での $\mathrm{Pt}(0.5 \mathrm{wt} \%) / \mathrm{ZnO}$ 触媒の経時変化を測定した結果を

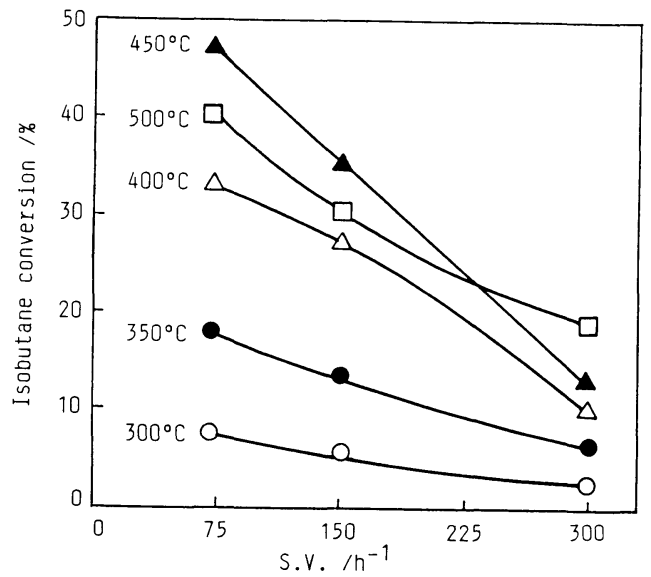

Fig. 6 Relationship between Conversion of Isobutane over $\mathrm{Pt}(0.5 \mathrm{wt} \%) / \mathrm{ZnO}$ Catalyst and Space Velocity

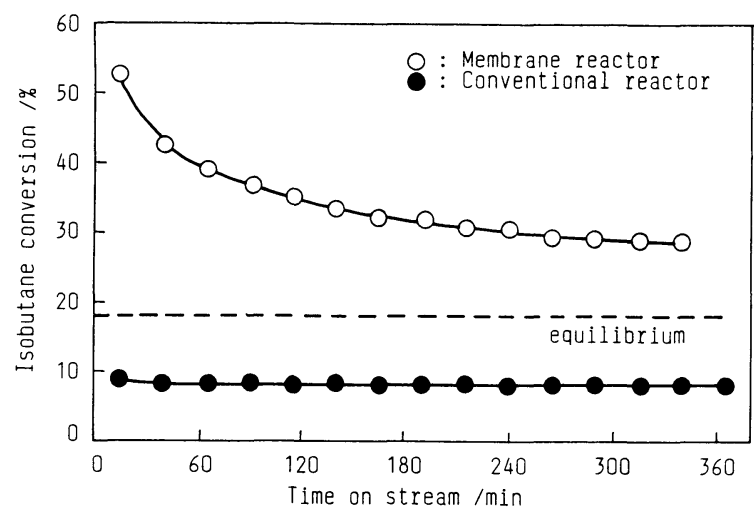

Fig. 7 Time Dependency of Conversion of Isobutane over $\mathrm{Pt}(0.5 \mathrm{wt} \%) / \mathrm{ZnO}$ Catalyst at $450^{\circ} \mathrm{C}$

Fig. 7 に示した。図より, 反応開始時には $50 \%$ 以上の転化率 であったものが，反応時間の経過に伴い徐々に低下し $28 \%$ 程 度でほほ定常になっているのがわかる。この経時変化の原因が $\mathrm{Pt}(0.5 \mathrm{wt} \%) / \mathrm{ZnO}$ 触媒の劣化によるものかどうかを確かめる ために, 非分離型反応器（触媒量 $0.5 \mathrm{ml}$ ）を用いた実験を行 い，その結果を同様に Fig. 7 に示した。これより, 非分離型 反応器を用いた場合にはほとんど活性の低下が生じていないこ とが明らかである。また，反応分離に用いた反応後の触媒の TG-DTA 分析において, 特に触媒上の炭素質の燃焼に伴う重 量減少が認められなかった。したがって，メンブレンリアク ターを用いたときの活性の低下は，触媒自身の劣化や触媒上、 の炭素質の析出によるものではなく, 水素分離膜の劣化を原因 として考えることができる。ここで, パラジウム令金膜の少化 の原因を探るための二，三の実験を行った。Fig. 8 は，イソ ブタンを反応原料としたときの $\mathrm{Pt}(0.5 \mathrm{wt} \%) / \mathrm{ZnO}$ 触媒の性能 に及ぼすスウィープガスの影響を示したものである。スウィー プガスとしてArを用いたときには，透過水素の酸化による反 灾促進作用がないために，空気をスウィープガスとしたときよ りも転化率は低いが, $500^{\circ} \mathrm{C}$ での活性低下は認められなかっ た。このことより, 膜の劣化の-・因としてパラジウム合金膜表 面の酸化をあげることができる。次に，Pt $\mathrm{P}(0.5 \mathrm{wt} \%) / \mathrm{ZnO}$ 触 


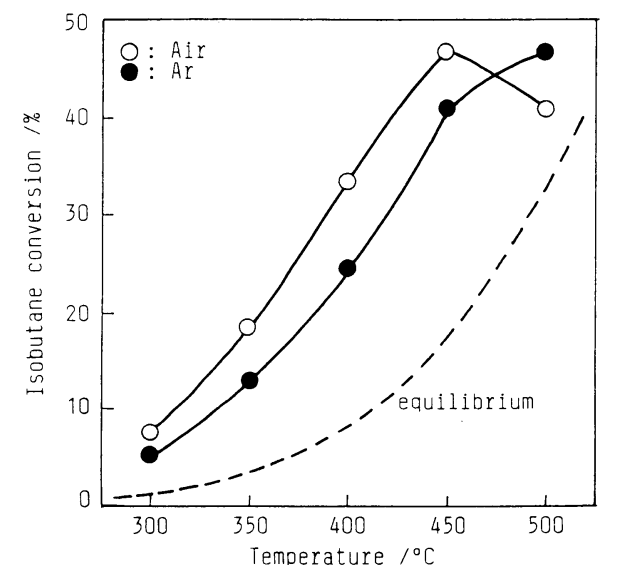

Fig. 8 Effect of Sweep Gas on Catalytic Activity of Pt $(0.5$ wt $\%) / 7 n$ O Catalyst

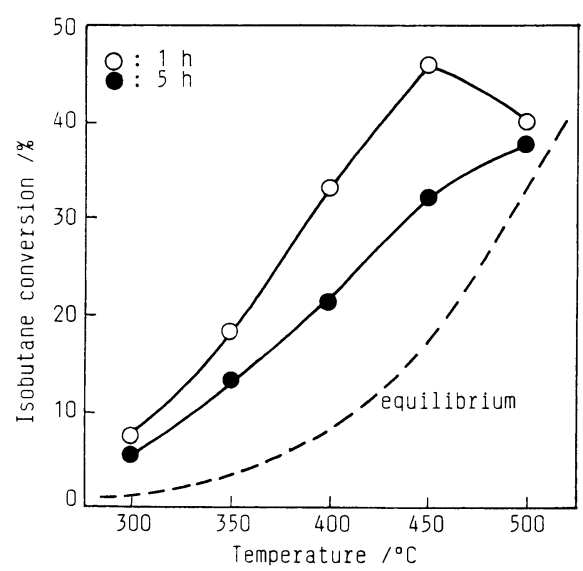

Fig. 9 Effect of Period of Reduction at $500^{\circ} \mathrm{C}$ on Catalytic Activity of $\mathrm{Pt}(0.5 \mathrm{wt} \%) / \mathrm{ZnO}$ Catalyst

媒の出発原料である塩化白金酸に起因する塩素（または $\left.\mathrm{ZnCl}_{2}\right)$ による膜の被毒を予想して,標準還元条件 $\left(500^{\circ} \mathrm{C}, 1 \mathrm{~h}\right)$ に代えて， $500^{\circ} \mathrm{C} 、 5 \mathrm{~h} て ゙$ 還元処理を行ったときの $\mathrm{Pt}(0.5$ $w \mathrm{t} \%) / \mathrm{Zn}($ ) 触媒のインブタンの脱水素父忍の結果を Fig. 9 に ホした。比較的高温での長時間の還元処理のためにPtのシン タリングが生じている川能性があり， $5 \mathrm{~h}$ 還元の触媒は $1 \mathrm{~h}$ 還

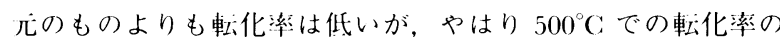
低下が生じていないことがわかる。予備集験において，反応管 内で触媒を還元した際に著しく転化率が減少していることから も，触媒から飛散した塩素が膜の劣化を促したことが考えられ る。さらに，パラジウム价金膜の劣化の程度を足量的に示すた

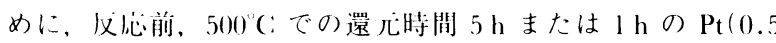
$w t \%) / \ln ()$ 触媒を用いた必忍後のパラジウム合金膜を用い て，それぞれ400(:でパラジウム命金膜を還元処理後，引き 続き问温度で水素透過速度(9)の測定を行い，その結果を Fig. 10 にホした。兴から明らかなように, 水素透過速度係数 $k$ は 他心後に減少して扔り，特にその低下の程度は⿻心忠させた触媒

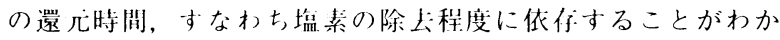
る。以トのことから，パラジウム食金膜の少化の原因として空

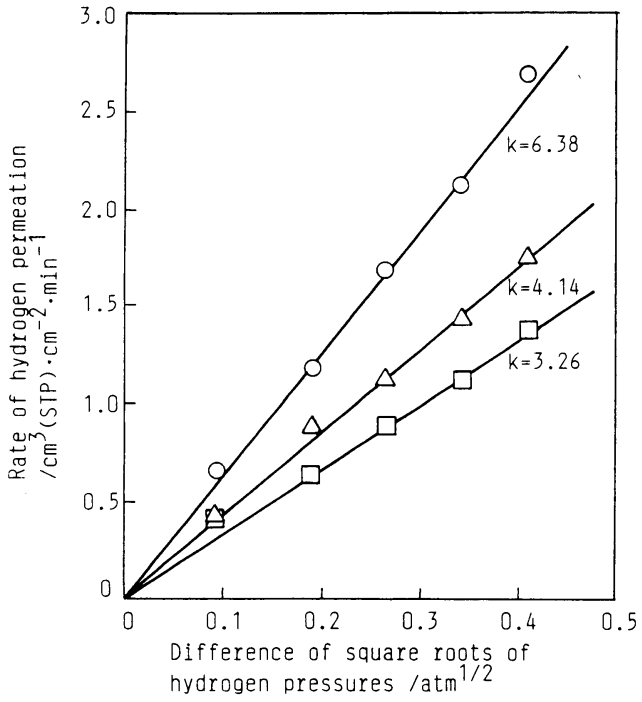

$\bigcirc$ : Before reaction.

$\triangle$ : After reaction using $\mathrm{Pt}(0.5 \mathrm{wt} \%) / \mathrm{ZnO}$ catalyst reduced for $5 \mathrm{~h}$.

$\square$ : After reaction using $\mathrm{Pt}(0.5 \mathrm{wt} \%) / \mathrm{ZnO}$ catalyst reduced for $1 \mathrm{~h}$

Fig. 10 Relationship between Rate of Hydrogen Permeation at $400^{\circ} \mathrm{C}$ and Difference in Square Roots of Partial Pressure of Hydrogen between High and Low Pressure Sides

気中の酸素による酸化や塩素による被毒をあげることができる が，塩素による被毒が起きれば透過水素量が減少しその結果と して酸化が促進されることが考えられる。

\section{5. 結}

水素分離のためにパラジウム合金膜を用い，透過水素を空気 により酸化除去する反応分離法により， $\mathrm{C}_{3}, \mathrm{C}_{4}$ パラフィンを 脱水素してオレフィンへ転化するための低温高活性触媒を開発 する目的で，主にPt 系触媒を中心に検討を加えた。その結 果, $\mathrm{Pt}(0.5 \mathrm{wt} \%) / \mathrm{ZnO}$ 触媒が比較的低温で平衡転化率を大き く上回る活性と非常に高いオレフィン選択性を示すことが明ら かになり，本反応に対する反応分離法の適用の叮能性を呈示し た。しかし，パラジウム令金膜の劣化が認められたことから， 今後はより以上の高活性をもつ触媒の開発を四るのはもちろん のこと，水素透過性にすぐれた分離膜の開発や反㐫方法の改良 を汹る必要がある。

\section{付 記}

本研究は通産省の補助金による（財）石油産業活性化セン 夕ー「新燃料油新規合成技術に関する調査」の委託による。

\section{References}

1) Orisaku, M., PETROTECH, 15, (1), 27 (1992).

2) Saima, M., PETROTECH, 15, (10), 972 (1992).

3) Itoh, N., AIChE J., 33, (9), 1576 (1987).

4) Uemiya, S., Sato, N., Ando, H., Matsuda, 'T., Kikuchi, E., Sekivu Gakkaishi, 33, (6), 418 (1990). 
5) Itoh, N., Ind. Eng. Chem, Prod. Res. Dev., 28, (10), 1554 (1989).

6) Igarashi, A., "Membrane Reactor Ouyo Handbook", eds. by Kokugan, Y., Matumoto, K., Science Forum, Tokyo (1990), p. 137

五十嵐, “メンブレンリアクター応用ハンドブック”, 国 眼, 松本編, サイエンスフォーラム社, 東京 (1990), p. 137.

7) Ogino, Y., "Gensobetsu Shokubai Binran”, ed. by Sho- kubai Gakkai., Chijin Shokan, Tokyo (1967), p. 368. 荻野, “元素別触媒便覧”, 触媒学会編, 地人書館, 東京 (1967), p. 368.

8) Furuoya, I., "Shokubai Chousei Kagaku", ed. by Ozaki, A., Kodansha, Tokyo (1980), p. 53. 古尾谷, “触媒調製化学”, 尾崎ほか編, 講談社, 東京 (1980), p. 53.

9) Itoh, N., Kagaku to Kogyo, 40, (10), 845 (1987).

\title{
Summary
}

\section{Dehydrogenation of Butanes and Propane over Pt/ZnO Catalyst with Palladium Membrane Reactor}

\author{
Akira Igarashi and Michitaka OHтA ${ }^{\dagger 1)}$ \\ Dept. of Chemical Engineering, Faculty of Engineering, Kogakuin University, Hachioji, Tokyo 192 \\ 1) (Persent) Research \& Development Lab., Nippon Steel Chemical Co., L.td., Tobata-ku, Kitakyushu, Fukuoka 804
}

Catalysts for low-temperature dehydrogenation of isobutane, $n$-butane, and propane were studied using a double-tube membrane reactor, the inner tube of which was a palladium-silver alloy membrane. The hydrogen produced by dehydrogenation at the reaction side permeated through the membrane and reacted with the oxygen in air at the separation side. Among the catalysts tested, $\mathrm{Pt}(0.5 \mathrm{wt} \%) / \mathrm{ZnO}$ catalyst was the most active for dehydrogenation of isobutane to isobutylene. The activity of $\mathrm{Pt}(0.5 \mathrm{wt} \%) / \mathrm{ZnO}$ catalyst was high compared to the thermodynamic equilibrium value attainable in a conventional reactor, and the catalyst could realize more than $45 \%$ conversion of isobutane and about $99 \%$ selectivity for isobutylene at $450^{\circ} \mathrm{C}$. The $\mathrm{Pt}(0.5 \mathrm{wt} \%) / \mathrm{ZnO}$ catalyst was also very effective for dehydrogenation of propane and $n$-butane. However, such results were observed: the poisoning of the catalyst caused probably by chlorine in the chloroplatinic acid, which was the platinum source, and the deactivation of the palladium alloy membrane caused probably by oxidation of the membrane.

Keywords

Dehydrogenation, Isobutane, Isobutylene, Palladium membrane reactor, Platinum catalyst, Zinc oxide support 